Agro-Science Journal of Tropical Agriculture, Food, Environment and Extension Volume 19 Number 1 (January 2020) pp. 54-60

ISSN 1119-7455

\title{
HOUSEHOLD FOOD SECURITY AND ITS DETERMINANTS IN AGRARIAN COMMUNITIES OF SOUTHEASTERN NIGERIA
}

\author{
Akukwe, Thecla Iheoma \\ Department of Geography, University of Nigeria, Nsukka, Enugu State, Nigeria \\ Author's email: thecla.akukwe@unn.edu.ng
}

\begin{abstract}
The study investigated household food security (food accessibility) and its determinants in eight agrarian communities of Southeastern Nigeria where food accessibility was measured using per capita monthly food expenditure, and households were classified into food secure and food insecure. Four hundred (400) households were selected using stratified and random sampling methods. The results revealed that the categorization of households into either food secure or food insecure was a function of money spent on food monthly and household size, making household food security status differ within and across households and communities. The general findings revealed that majority (53.5\%) of households were food insecure while $46.5 \%$ were food secure. Oguta community was revealed as the most food secure because majority of her households (68\%) recorded relatively high per capita monthly food expenditure coupled with small household sizes while the reverse is the case with Ossomala community where $67.2 \%$ of households were food insecure. The Logistic regression analysis run to show the relationship between food security status and 23 predictors drawn from literature and observation, showed that only five were significant $(p<0.05)$ namely (with their coefficients) marital status (-0.347), level of education (0.540), monthly income (1.719), dependency ratio (-3.385) and distance to market $(-0.880)$. The direction of their regression coefficients revealed that households headed by unmarried persons with higher level of education and monthly income as well as with fewer dependants were more food secure, and food security decreased with increasing distance to market in Southeastern Nigeria.
\end{abstract}

Key words: food secure, food accessibility, agrarian, food expenditure, food insecure

\section{INTRODUCTION}

Global agricultural production has recorded an incredible increase (Ibok Idiong et al., 2014), even though a large number of people remain hungry and malnourished (Ambali et al., 2015). According to FAO (2010), 925 million people were approximately undernourished in 2010 with about 900 million of them living in developing countries while FAO (2015) estimated 217.8 million undernourished people to be living in Sub-Saharan African between 2014 and 2016. Moreover, more than $70 \%$ of these undernourished people live in rural areas where agriculture is directly or indirectly reliant upon (Bashir et al., 2012).

Similarly, about 1.2 billion people cannot meet their most basic needs for sufficient food every day especially poor people living in rural environments in developing countries who are subsistence farmers (IFAD, 2009). Consequently, Nigeria has been listed among the 55 Low Income Food Deficit (LIFD) countries due to the high prevalence of undernourished people living among agricultural households (Ambali et al., 2015).

In Nigeria, agriculture is the mainstay of the country's economy (IFAD, 2012), going by the fact that agricultural sector contributes about $40 \%$ to the economy and provides a livelihood for about $90 \%$ of the rural population (Federal Republic of Nigeria, 2008; FAO 2011; National Bureau of Statistics, 2012). Despite the contribution of agriculture to Nigeria's economy, subsistence farming is widely practised with up to $90 \%$ of food in the country being produced by micro-scale farmers with small land holdings who practise mainly rain-fed agriculture. However, widespread food insecurity in Nigeria has been attributed to poor agricultural output and prevalent poverty in the country with an estimated $70 \%$ of Nigerians suggestively being food insecure (Orewa and Iyanbe 2009; Obayelu, 2010; Kuku-Shittu et al., 2013).

Food security, according to FAO (1996, 2008a), exists when all people, at all times, have physical and economic access to sufficient, safe and nutritious food that meets their dietary needs and food preferences for an active and healthy life. The definition of food security as seen above consists of four dimensions namely; food accessibility, availability, utilization and stability. Food availability has to do with "Sufficient food" and is associated with physical quantities of food while food accessibility is a measure of the ability to obtain/secure food. Food utilization entails the 
consumption of food and how essential nutrients are acquired from consumed food by a person while stability deals with the phrase "at all times" in the food security definition by FAO (1996, 2008a). To this end, accomplishing a state of food security by an/a individual, household, region or country requires arriving at an adequate level of good nutrition and food consumption and maintaining this level at low risk over time (FAO, 2008a, 2008b). Consequently, food insecurity situation exists whenever one of the above conditions is not met or there is any negative shift in any of the dimensions of food security (Akukwe, 2019).

Food security as noted by Ogundari (2017), had been measured globally using various indicators which include; per capita expenditure on food, food insecurity access scale (self-report/assessment), food consumption score, per capita food consumption, anthropometry measures, share of dietary intake and coping strategy index among others. Paradoxically, despite extensive studies on food security indicators, there is no agreement on the core indicators that are needed to satisfactorily measure and examine household food security situations at both the micro- and macro-levels around the world (Carletto, Zezza and Banergec, 2013) because these indicators only revolves round one dimension at a time. However, despite the extensive food security evaluation methods, measuring food security status at household level seemed neglected as supported by Ojogho (2010) and Dawit and Zeray (2017) since most studies had measured food security at the national and regional levels. Nonetheless, this study focused on food accessibility dimension of food security that deals with the ability to obtain/secure food, and had adopted the per capita expenditure on food which measures food security on the basis of money spent on food monthly, against the household size. The choice of the per capita expenditure method was informed by the ease of generating/obtaining data on household size and monthly food expenditure from households' heads, and due to non-existence of food security data at the household level in the study area.

There exists extant literature on the determinants of household food security classified into demographic, socio-economic and physical factors such as; sex and age of head of household, household size, land holding (farm size), membership to agricultural cooperative, climatic adaptation, agricultural technology, shocks, distance to the market, income diversification, household asset index, sufficiency in own food production, dependency ratio, farm size, income, level of education, livestock ownership, credit access, marital status (Arene and Anyaeji, 2010; Bashiri et al., 2012; Ahmed and Dotti, 2014; Welderufael, 2014; Habyarimana,2015; Djangmah, 2016; Goshu, 2016; Ndakaza et al., 2016; Ajaero, 2017; Dawit and Zeray, 2017; Ogundari, 2017).
The adopted determinants of household food security status for this study were drawn from the extant literature and observations taking into cognizance that the study area is generally agrarian and has comparative advantage in the production of crops like potatoes, yams, maize and cassava (staples) in Nigeria. Thus, the study geared towards assessing food security status of households in agrarian communities of south eastern Nigeria, and discussed the significant determinants of food security among these households and communities.

\section{MATERIALS AND METHODS}

\section{Study Area and Sampling Techniques}

The study was carried out in two states namely Imo and Anambra States in Southeastern Nigeria. Four local government areas (LGAs) were purposively selected in the two states namely; Ohaji/Egbema and Oguta LGAs in Imo State; Ogbaru and Anambra East LGAs in Anambra State. Two communities were then selected in each LGA, giving a total of eight agrarian communities selected on the basis of accessibility (Figure 1). The population of the four LGAs was 700,697 persons (National Population Commission, 2010), and the sample size for the study was calculated by Yamane's (1967) equation where the sample size for any population $\geq 100,000$ persons at $\pm 5 \%$ precision level is 400 as given below.

$$
n=N \div\left[1+N\left(e^{2}\right)\right]
$$

where $n$ is the sample size (400 households), $N$ is the population of the four LGAs of the study (Anambra East, Ogbaru, Oguta and Ohaji/Egbema) and $e$ is the level of precision/sampling error, i.e., 0.05 . The number of households sampled in each community was determined using stratified sampling method while the copies of questionnaire were distributed via random sampling.

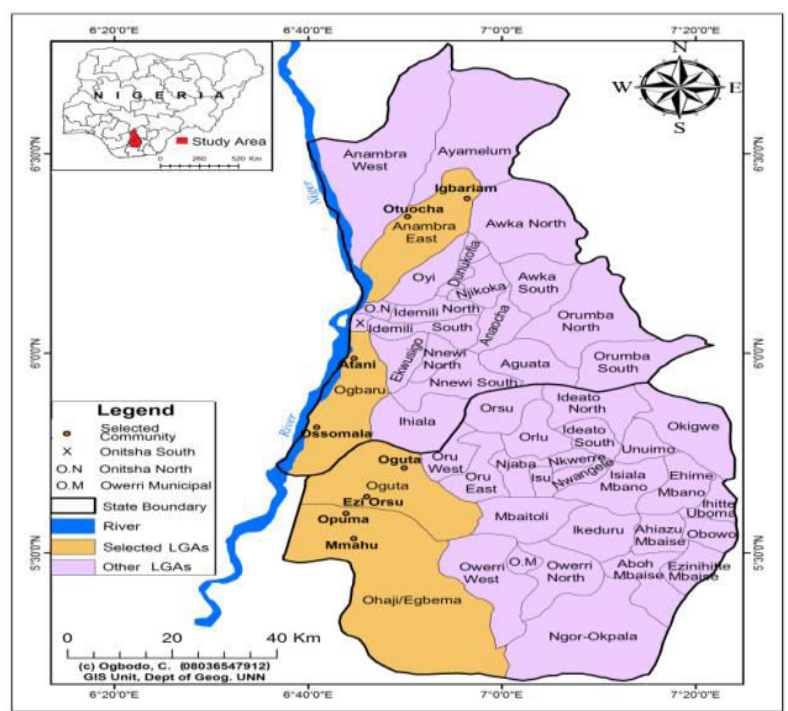

Figure 1: Map of the study area showing the sampled LGAs/communities

Source: GIS Lab., Department of Geography, University of Nigeria, Nsukka, 2016 


\section{Household Food Security Measurement}

The Household Food Security Index (FSI) used to assess the food accessibility dimension of food security was calculated according to Omonona and Agoi (2007) as shown in the equation below.

$$
\text { FSI }=\frac{\begin{array}{c}
\text { Per capita monthly food } \\
\text { expenditure for the ith household }
\end{array}}{\frac{2}{3} \text { mean per capita monthly }} \ldots \ldots \ldots \ldots \ldots \ldots
$$

where FSI is general food security index; FSI $\geq 1$ is interpreted as food secure $i^{\text {th }}$ household and FSI $<1$ is interpreted as food insecure $i^{\text {th }}$ household.

A food secure household is any household whose per capita monthly food expenditure is equal to or more than $2 / 3$ of the mean per capita monthly food expenditure of all households, while a food insecure household is any household whose per capita monthly food expenditure is less than $2 / 3$ of the mean per capita monthly food expenditure of all households (Omonona and Agoi, 2007:402). The per capita monthly food expenditure for each household was calculated by dividing the monthly food expenditure by the household size. Relationship between food security and its predictors Binary logistic regression was employed to examine the determinants of food security in the study area with food security status as the dependent variable, Y, and its determinants as the independent variables, $\mathrm{X}$, as shown in the equation below.

$[Y /(1-Y)]=b_{0}+b_{1 \times 1}+b_{2 \times 2}+\cdots b_{23 \times 23} \ldots \ldots(3)$

where $[Y /(1-Y)]$ is the probability of a household being food secure/insecure, $b_{0}$ is the constant that scales the equation, $b_{1}$ to $b_{23}$ are the coefficients that determine the direction and extent to which the $(x)$ factors affect food security status $(Y)$, and $x_{1}$ to $x_{23}$ are factors that influence food security such as age of household head, sex of household head, monthly income (presented later).

The logit model was chosen because it does not make assumptions regarding normality, linearity and homoscedasticity, e.g., the logit model does not require a linear relationship between the predictors and the binary (dichotomous) dependent variable (food secure/food insecure).

The determinants of food security were some measurable demographic, physical and socioeconomic variables drawn from literature and observation. The 23 independent variables were mostly categorical measured through the use of indicators (via questionnaire) and where ordinal scale of measurement was involved (e.g. level of education ranging from "no formal education" through completing primary school to graduating from a University), data were transposed into two groups ("no formal education" and "educated") to show binary relationship.

\section{RESULTS AND DISCUSSION \\ Assessment of Food Expenditure and \\ Food Security Status}

In this study, food security means food accessibility considered to be a measure of the ability to obtain and/or secure food. This food accessibility was determined by food affordability and food expenditure (money spent on food).

Table 1 shows the households' monthly food expenditure, with the minimum money spent on food being four thousand Naira $(\mathrm{N} 4,000)$ and the maximum being twenty-eight thousand Naira (N28,000) while on average households' monthly food expenditure was fourteen thousand, two hundred and twenty-two Naira (N14,222.00). Majority of households $(81 \%)$ spent between ten to twenty thousand Naira (N10,000 to 21,000) monthly on food and this was partly as a result of large household size recorded in the study area. The size ranged from 1 to 9 persons with a mean size of 5 persons in the entire agrarian communities.

Table 2 shows the FSI for the eight communities as computed with per capita monthly food expenditure (shown in eq. 2). The results reveal that households in Oguta LGA (Oguta and Ezi-Orsu communities) were more food secure while households in Mmahu, Otuocha, Atani, Igbariam and Ossomala communities (in an increasing order) were more food insecure. Opuoma community recorded an equal percentage of households in the food secure and food insecure categories. The categorization of households into either food secure or food insecure is a function of money spent on food monthly and household size. For example, Oguta was the most food secure $(68 \%)$ community largely due to her recording relatively high per capita monthly food expenditure coupled with small household sizes while the reverse is the case with Ossomala community where $67.2 \%$ of households were food insecure.

Table 1: Households' monthly food expenditure

\begin{tabular}{lcc}
\hline Monthly food expenditure & Frequency & Percent \\
\hline $4000-9000$ & 55 & 13.7 \\
$10000-15000$ & 160 & 40.0 \\
$16000-21000$ & 164 & 41.0 \\
$22000-28000$ & 21 & 5.3 \\
Total & 400 & 100.0 \\
Mean & $\mathrm{N} 14222.00$ & \\
\cline { 2 - 3 }
\end{tabular}

Source: Researcher's computation, 2017

Table 2: Household food security status using per capita monthly food expenditure

\begin{tabular}{lccc}
\hline \multirow{2}{*}{ Community } & \multicolumn{2}{c}{ Food Security Status } & Total \\
& Food secure & Food insecure & \\
\cline { 2 - 4 } Osani & $27(42.2 \%)$ & $37(57.8 \%)$ & $64(100.0 \%)$ \\
Otuocha & $21(32.8 \%)$ & $43(67.2 \%)$ & $64(100.0 \%)$ \\
Igbariam & $21(47.7 \%)$ & $23(52.3 \%)$ & $44(100.0 \%)$ \\
Oguta & $17(39.5 \%)$ & $26(60.5 \%)$ & $43(100.0 \%)$ \\
Ezi-Orsu & $28(68.3 \%)$ & $13(31.7 \%)$ & $41(100.0 \%)$ \\
Mmahu & $21(52.5 \%)$ & $19(47.5 \%)$ & $40(100.0 \%)$ \\
Opuoma & $25(48.1 \%)$ & $27(51.9 \%)$ & $52(100.0 \%)$ \\
Total & $26(50.0 \%)$ & $26(50.0 \%)$ & $52(100.0 \%)$ \\
\hline
\end{tabular}

Source: Researcher's computation, 2017 
A cross tabulation analysis of food security categories within communities is shown in Figure 2. With respect to food insecure households across the eight agrarian communities, Ossomala recorded the highest $(20.1 \%$ ), followed by Atani with $17.3 \%$ food insecure households across Southeastern Nigeria. Oguta and Ezi-Orsu communities recorded the least number (6.1 and $8.9 \%$, respectively) of food insecure households. Figure 2 reveals that Oguta LGA (Ezi-Orsu and Oguta communities) was the least food insecure while Ogbaru LGA (Atani and Ossomala communities) was the most food insecure as regards food accessibility in south eastern region of Nigeria.

Analysis of the Relationship between Food Security Status and Its Determinants

The result of the Logistic regression analysis showing the relationship between household food security status and its determinants is shown in Table 3. Twenty-three variables were identified as predictors of food security status in Southeastern Nigeria, out of which only five were statistically significant at $0.05 \%$ level of significance. The findings revealed marital status, level of education, monthly income, dependency ratio and distance to market as the statistically significant variables that determined household food security status in the study area. In addition, the Cox and Snell, coefficient of determination, $R^{2}$ was .476 indicating a $47.6 \%$ probability of the food security status being explained by the logistic model, and with an $82.8 \%$ correct classification, the model is good.

\section{Marital Status of Head of Household}

Marital status was significant at 5\% and the coefficient indicated that households headed by married people are more probable to be food insecure than those headed by unmarried people. It could be deduced from the findings that unmarried people were more food secure because of their smaller household sizes and fewer people to feed. The finding is in line with that of Aidoo et al. (2013), but runs contrary to the findings of Sekhampu (2013) in South Africa; Habyarimana (2015) in Rwanda; Yusuf et al. (2015) in Nigeria and Djangmah (2016) in Ghana where households headed by married people were found to be more food secure than their unmarried counterparts. The odds ratio showed that households headed by unmarried people are 0.706 times likely to be food secure than those headed by married people (Table 3 ).

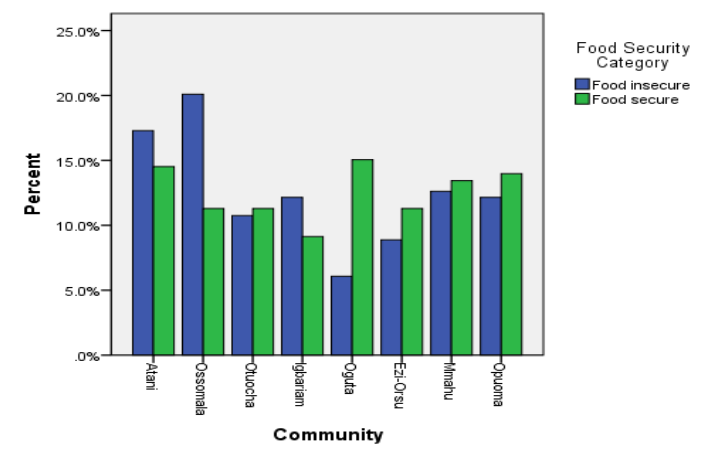

Figure 2: Community food security category based on per capita monthly food expenditure

Table 3: Logit model output of determinants of food security status

\begin{tabular}{|c|c|c|c|c|c|c|}
\hline Variable & $\mathrm{B}$ & S.E. & Wald & df & Sig. & $\operatorname{Exp}(\mathrm{B})$ \\
\hline Gender & .423 & .408 & 1.077 & 1 & .299 & 1.527 \\
\hline Age & -.169 & .152 & 1.231 & 1 & .267 & .845 \\
\hline Marital status & -.347 & .139 & 6.266 & 1 & $.012 *$ & .706 \\
\hline Literacy rate & -.465 & .560 & .690 & 1 & .406 & .628 \\
\hline Education level & .540 & .265 & 4.140 & 1 & $.042 *$ & 1.716 \\
\hline Diversified income & .322 & .863 & .140 & 1 & .709 & 1.381 \\
\hline Off-farm income & -.335 & .820 & .167 & 1 & .683 & .715 \\
\hline Monthly income & 1.719 & .258 & 44.338 & 1 & $.000 *$ & 5.581 \\
\hline Dependant ratio & -3.385 & .469 & 52.050 & 1 & $.000 *$ & .034 \\
\hline Group membership & -.268 & .401 & .448 & 1 & .503 & .765 \\
\hline Land ownership & .358 & .452 & .627 & 1 & .429 & 1.430 \\
\hline Sufficient food production & -.651 & .452 & 2.069 & 1 & .150 & .522 \\
\hline Livestock ownership & -.156 & .408 & .147 & 1 & .702 & .855 \\
\hline VP/Poultry ownership & .116 & .385 & .091 & 1 & .763 & 1.123 \\
\hline Distance to farm & -.554 & .420 & 1.742 & 1 & .187 & .575 \\
\hline Distance to market & -.880 & .358 & 6.036 & 1 & $.014 *$ & .415 \\
\hline Storage facility & .343 & .395 & .757 & 1 & .384 & 1.410 \\
\hline Fertilizer use & .198 & .394 & .251 & 1 & .616 & 1.218 \\
\hline Irrigation practice & -1.084 & .629 & 2.971 & 1 & .085 & .338 \\
\hline Food/Aid receipt & -.687 & .399 & 2.958 & 1 & .085 & .503 \\
\hline Farm size & .055 & .087 & .398 & 1 & .528 & 1.056 \\
\hline Financial support & -.215 & .428 & .252 & 1 & .616 & .807 \\
\hline Credit access & 1.075 & .769 & 1.954 & 1 & .162 & 2.930 \\
\hline Constant & -.406 & 1.207 & .113 & 1 & .736 & .666 \\
\hline -2 Log likelihood & 294.182 & & & & & \\
\hline Cox and Snell $R^{2}$ & .476 & & & & & \\
\hline Nagelkerke $R^{2}$ & .635 & & & & & \\
\hline
\end{tabular}




\section{Level of Education of Head of Household}

The regression result revealed a significant (5\%) positive relationship between the level of education of households' heads and households' food security, meaning that food security increases with higher level of education ceteris paribus.

Education, according to Ibok Bassey et al. (2014), is a social capital which influences people's nutritional and production decisions; so it is explanatory when households headed by persons with higher level of education were found to be more food secure in the study area. The findings also revealed that households were 1.716 times more likely to be food secure with each unit increase in level of education (Table 3 ). The result is in tandem with Tefera and Tefera (2014), Wiranthi et al. (2014), Mutinda (2015), Ajaero (2017) and Dawit and Zeray (2017), but contrary to Yusuf et al. (2015) and Djangmah (2016), who found food security to decrease with increasing number of years spent in education in Nigeria and Northern region of Ghana respectively.

\section{Monthly Income of Head of Household}

The coefficient of monthly income of households' heads was positive and significant at 5\% level indicating that household food security increases with higher level of a household monthly income and vice versa. Income has remained a critical factor that influences food accessibility (ability to secure/obtain food) and as noted by Battersby (2011), income makes a significant difference in reducing (though not eliminate totally) food insecurity. Also, income influences household monthly food expenditure. The finding agrees with those of Idrisa et al. (2008), Battersby (2011), Bashiri et al. (2012), Aidoo et al. (2013), Henri-Ukoha et al. (2013), Sekhampu (2013), Mungai (2014), Mutinda (2015) and Djangmah (2016). The odds ratio in favour of households to be food secure increased by 5.581 times for every increase in a household's head monthly income (Table 3 ). The implication is that households with higher monthly income are 5.581 times more probable to be more food secure than households with lower monthly income.

\section{Dependency Ratio of Household}

The coefficient of dependency ratio was significant at 5\% level and had a negative relationship with the food security status of the agrarian households, meaning that a household with larger number of dependants (> 5 persons) is more likely to be food insecure than a household with fewer dependants. This is indicative of the fact that pressure is put on household resources when the number of dependants is larger vis-à-vis monthly income of the household, and this increases the probability of being food insecure. This also explains why single persons were more food secure than their married counterparts. This finding is in agreement with the findings of Idrisa et al. (2008), Asogwa and Umeh (2012), Aidoo et al. (2013), Sekhampu (2013), Ibok Bassey et al. (2014), Mutinda (2015); Djangmah (2016); Goshu (2016) and Dawit and Zeray (2017), but contradicts the findings of Oluoko-Odingo (2006) and Ajaero (2017) who found households with higher number of dependants to be more food secure. The odds ratio of .034 implies that, for every increase in number of dependants in a household, there is .034 times of that household becoming food insecure (Table 3 ).

\section{Distance to Market}

The result revealed a significant (5\%) negative relationship between distance to market (access to market) and households' food security status. The implication is, households closer to the market (both daily and periodic) are more likely to be food secures than those far from the market ceteris paribus, and this agrees with findings of OluokoOdingo (2006); Goshu (2016) and Ndakaza et al. (2016). Table 3 shows that a unit increase in distance to the market reduces the likelihood of becoming food insecure by a factor of 0.415 .

\section{CONCLUSION AND RECOMMENDATIONS}

The study investigated household food security (food accessibility) and its determinants in agrarian communities of Southeastern Nigeria. Food accessibility which is the ability to secure and/or obtain food was measured using per capita monthly food expenditure, and thereafter households were classified into food secure and food insecure. Generally, the results showed that households $(53.5 \%)$ in the eight agrarian communities were food insecure while the remaining $(46.5 \%)$ were food secure. There was an observed variation between and within households across the sampled communities and LGAs with Oguta LGA (Oguta and Ezi-Orsu communities) being more food secure and Ogbaru LGA (Atani and Ossomala communities) being more food insecure as regards food accessibility in south eastern region of Nigeria. Relatively high per capita monthly food expenditure coupled with small household sizes have been attributed to the reason for Oguta community being the most food secure while the reverse is the case with Ossomala community where $67.2 \%$ of households were food insecure. The study considered 23 demographic, physical and socio-economic predictors drawn mostly from literature, and the logistic regression analysis was run to show the relationship between these determinants and household food security status.

The regression result revealed marital status, level of education, monthly income, dependency ratio and distance to market as the statistically significant $(p<0.05)$ variables that determined household food security status in the study area. 
Inferring from the regression coefficients, households headed by unmarried persons with higher level of education and monthly income as well as with fewer number of dependants ( $<5$ persons) were more food secure, and food security decreased with increasing distance to market (proxy for access to market) in Southeastern Nigeria.

However, the obvious presence of food secure and food insecure categories across households and communities irrespective of monthly income, level of education, dependency ratio, access to market and marital status is indicative of the fact that no factor can be singled out as the only determinant of food security status in the study area. Therefore, recommendations based on the study findings include; sensitization of households' heads on the practice of family planning to discourage larger household size and dependency ratio; strategies to improve households' monthly income earnings and policy measures that encourage access to education (subsidized or free) for households to enhance food security in the agrarian communities.

\section{REFERENCES}

Ahmed F.F. and Dotti R.Y. (2014). Food security and coping strategies amongst medium income earners in Maiduguri metropolis of Borno State, Nigeria. Journal of Humanities \& Social Sci., IOSR, 19 (1), Ver. IX, 1-8

Aidoo R., Mensah J.O. and Tuffour T. (2013). Determinants of household food security in the Sekyere-Afram Plains District of Ghana. $1^{\text {st }}$ Annual International Interdisciplinary Conference, AIIC, Proceedings, Azores, Portugal, 514-521

Ajaero C.K. (2017). A gender perspective on the impact of flood on the food security of households in rural communities of Anambra State, Nigeria. Food Security, 9 (4), 685-695

Akukwe T.I. (2019). Spatial Analysis of the Effects to Flooding on Food Security in Agrarian Communities of South eastern Nigeria (Unpublished PhD thesis). Department of Geography and Environmental Studies, University of Nairobi, Kenya

Ambali O.I., Adewuyi S.A., Babayanju S.O. and Ibrahim S.B. (2015). Expansion of rice for job initiative programme: implications for household food security in Lagos State Nigeria. Advances in Economics \& Business, 3 (3), 99-106. DOI: 10.13189/aeb.2015.030303. http://www.hrpub.org

Arene C.J. and Anyaeji R.C. (2010). Determinants of food security among households in Nsukka Metropolis of Enugu State, Nigeria. Pakistan Journal of Social Sciences, 30 (1), 9-16

Asogwa B.C and Umeh J.C. (2012, December). Food insecurity determinants among rural farm households in Nigeria. International Conference on Ecology, Agriculture and Chemical Engineering (ICEACS), Phuket (Thailand)

Bashir M.K., Schilizzi S. and Pandit R. (2012). The determinants of rural household food security for landless households of the Punjab, Pakistan. Working Paper 1208, School of Agricultural \& Resource Economics, University of Western Australia, Crawley, Australia
Battersby J. (2011). The State of Urban Food Insecurity in Cape Town. (Urban Food Security Series No. 11). Kingston and Cape Town: Queen's University and AFSUN

Carletto C., Zezza A. and Banergec R. (2013). Towards better measurement of household food security: harmonizing indicator and the role of household surveys. Glob. Food Sec. 26, 30-40

Dawit D. and Zeray N. (2017). Determinants of rural household food security in Wolaita Zone: the case of Humbo Woreda. Journal of Poverty, Investment \& Development 32, 65-82

Djangmah G.M. (2016). Comparative Analysis of Food Security Status of Farming Households in Eastern and Northern Regions of Ghana (Unpublished MSc Project). Department of Agricultural Economics, McGill University, Montreal; Quebec, Canada

FAO (1996). Rome Declaration on World Food Security and World Food Summit Plan of Action. Rome: FAO Document Repository

FAO (2008a). Food security concepts and frameworks: food security information for action, e-learning manual. Retrieved from: http://www.fao.org/elearning/Course/ FC/en/Course Viewer.asp?language $=e n$ at 01:20 am Thu 25/06/2015

FAO (2008b). Climate change and food security: a framework document. Rome: The Food and Agriculture Organization of the United Nations

FAO (2010). The state of food insecurity in the world: addressing food insecurity in protracted crises. Rome: Food and Agricultural Organisation of the United Nations

FAO (2011). The state of food and agriculture, 20102011: women in agriculture - closing the gender gap for development. Rome: FAO

FAO (2015). Regional overview of food insecurity: African food security prospects brighter than ever. Accra: FAO

Federal Republic of Nigeria (FRN, 2008). National Food Security Programme, Federal Ministry of Agriculture and Water Resources

Goshu M.T. (2016). Determinants of Rural Food Security and Child Nutrition: The Case Study of Gubalafto District of Amhara Regional State, Ethiopia (Unpublished PhD thesis). Department of Economics, Aligarh Muslim University Aligarh, India

Habyarimana J.B. (2015). Determinants of household food insecurity in developing countries: evidences from a probit model for the case of rural households in Rwanda. Sustainable Agriculture Research, 4 (2). DOI: http://dx.doi.org/10.5539/sar.v4n2p78

Henri-Ukoha A, Ibekwe U.C., Chidiebere-Mark N.M., Ejike R. and Oparadim (2013). Determinants of food security in female-headed households involved in individual tenure system in Abia State, Southeast Nigeria. Global Journal of Agric. Res. 1 (2), 48-57

Ibok O.W., Bassey N.E., Atairet E.A. and Obot O.J. (2014). Food security determinants among urban food crop farming households in Cross River State, Nigeria. Asian Journal of Agricultural Extension, Economics \& Sociology, 3 (1), 76-90

Ibok O.W., Idiong I.C., Brown I.N., Okon I.E. and Okon U.E. (2014). Analysis of food insecurity status of urban food crop farming households in Cross River State, Nigeria: A USDA approach. Journal of Agricultural Science, 6 (2), 132-141 
Idrisa Y.L., Gwary M.M. and Shehu H. (2008). Analysis of food security status among farming households in Jere Local Government of Borno State, Nigeria. Agro-Science, 7 (3), 199-205

International Fund for Agricultural Development, IFAD (2009). Dimensions of rural poverty. Rural Poverty Portal. Retrieved from http://www.ruralpovertyportal. org/topic

International Fund for Agricultural Development, IFAD (2012). Enabling poor rural people to overcome poverty in Nigeria. IFAD: Rome. Retrieved from www. ruralpovertyportal.org/country/statistics/tags/Nigeria

Kuku-Shittu O., Mathiassen A., Wadhwa A., Myles L. and Ajibola A. (2013). Comprehensive food security and vulnerability analysis Nigeria (Discussion Paper 01275). Washington, DC: The International Food Policy Research Institute/World Food Programme

Mungai O.K. (2014). Determinants of household food security in Lugari and Makueni Sub-counties, Kenya (Unpublished MSc project), Department of Economics, School of Economics, University of Nairobi

Mutinda G.B. (2015). Determinants of Household Food Expenditure and Food Security in Rural Kenya (Unpublished MSc project). Department of Economics, University of Nairobi.

National Bureau of Statistics, NBS (2012). Nigeria Poverty Profile 2010. Abuja, Nigeria

National Population Commission, NPC (2010). 2006 Population and Housing Census: Population Distribution by Sex, State, LGA and Senatorial District (Priority Table Volume III). Abuja: National Population Commission, Abuja, Nigeria

Ndakaza J.N., Mung'atu J.K., Ndengo M., Hagenimana F., Gasheja C. and Harerimana, J. (2016). Modeling key determinants of the household food security in Rwanda: probit regression approach. International Journal of Mathematics \& Physical Sciences Research, 4 (2), 85-94

Obayelu A.E. (2010). Classifications of Households into Food security status in the North Central Nigeria: an application of Rasch measurement model. Journal of Agricultural \& Biological Sciences, 5 (3), 26-41
Ogundari K. (2017). Categorizing households into different food security states in Nigeria: the socioeconomic and demographic determinants. Agric. Food Economics 5 (8). DOI 10.1186/s40100-017-0076-y

Ojogho O. (2010). Determinants of food insecurity among arable framers in Edo State, Nigeria. Agricultural Journal, 5 (3), 151-156

Oluoko-Odingo A.A. (2006). Food security and Poverty among Small-Scale Farmers in Nyando District, Kenya (Unpublished PhD thesis). Department of Geography and Environmental Studies, University of Nairobi

Omonona B.T. and Agoi G.A. (2007). An analysis of food security situation among Nigerian urban households: evidence from Lagos State, Nigeria. Journal of Central European Agriculture, 8 (3), 397-406

Orewa S.I. and Iyanbe C.O. (2009). Household food insecurity in nigeria: an assessment of the present status of protein-energy malnutrition among rural and low-income urban households. Journal of Applied Sciences Research, 5 (10), 1615-1621

Sekhampu T.J. (2013). Determinants of the food security status of households receiving government grants in Kwakwatsi, South Africa. Mediterranean Journal of Social Sciences, 4 (1), 147-153. DOI: 10.5901/mjss.2013.v4n1p147

Tefera T. and Tefera F. (2014). Determinants of households food security and coping strategies for food shortfall in Mareko District, Guraghe Zone Southern Ethiopia. Journal of Food Security, 2 (3), 92-99

Welderufael M. (2014). Determinants of households vulnerability to food insecurity in Ethiopia: econometric analysis of rural and urban households. Journal of Economics \& Sustainable Development, 5 (24) http://www.iiste.org/Journals/index.php/JEDS/article/v iew/17506

Wiranthi P.E., Suwarsinah H.K., Adhi A.K (2014). Determinants of household food security: a comparative analysis of Eastern and Western Indonesia. Indones. J. Agric. Sci., 15 (1), 17-28

Yamane T. (1967). Statistics: An Introductory Analysis $\left(2^{\text {nd }}\right.$ ed.). New York: Harper and Row

Yusuf S.A., Balogun O.L. and Falegbe O.E. (2015). Effect of urban household farming on food security status in Ibadan metropolis, Oyo State, Nigeria. Journal of Agricultural Sciences, 60 (1), 61-75 